Sains Malaysiana 49(8)(2020): 1935-1945

http://dx.doi.org/10.17576/jsm-2020-4908-15

\title{
Kecekapan Filem Kanji/Minyak Kayu Manis sebagai Pembungkus Makanan dengan Sifat Antimikrob
}

(Effectiveness of Starch/Cinnamon Oil Film as Food Packaging with Antimicrobial Properties)

\author{
Ummi Habibah AbDullah, IshaK AHMaD*, Ainon HAMZAH \& NoOR AfizaH Rosli
}

\begin{abstract}
ABSTRAK
Dalam kajian ini, filem kanji/minyak kayu manis telah dihasilkan menggunakan kaedah pengacauan larutan dengan kandungan minyak kayu manis (MKM) berbeza untuk mengkaji kesan MKM terhadap sifat antimikrob filem kanji. Sifat kelutsinaran filem didapati berkurang apabila peratus kandungan MKM meningkat yang telah menghalang penembusan cahaya. Sementara itu, analisis ATR-FTIR mendapati bahawa tiada penyesaran puncak atau pembentukan puncak baharu yang menunjukkan bahawa MKM dan filem kanji tidak terikat secara kimia. Kajian aktiviti antimikrob filem ini terhadap Bacillus cereus dan Aspergillus niger telah mendapati berlakunya peningkatan kecekapan aktiviti antimikrob bagi penambahan minyak kayu manis (MKM) dengan peningkatan diameter zon perencatan. Didapati berlaku perencatan pada kepekatan minimum MKM ditingkatkan bermula $16 \%$ dalam filem kanji mencatatkan corak pertumbuhan dalam zon rencatan dengan diameter 24-44.2 mm dengan peningkatan 28.23-37.88\% dan 34.12-52\%, masing-masing bagi zon perencatan terhadap B. cereus dan A. niger berbanding tiada sebarang zon perencatan untuk filem kanji tanpa penambahan MKM. Pemerhatian morfologi menunjukkan pembentukan liang dan pemisahan fasa yang heterogen antara MKM dan kanji. Tegangan maksimum filem pula menunjukkan pengurangan kekuatan tegangan apabila kepekatan MKM bertambah walaupun tidak ketara pada peningkatan MKM sehingga 24\%. Sebaliknya, terikan pada takat putus filem didapati meningkat sebanyak 102-252\% selari dengan penambahan MKM yang bertindak sebagai agen pemplastikan. Keseluruhannya, filem kanji/MKM telah berjaya disediakan dan pencirian sifat fizikal dan aktiviti antimikrob bagi filem ini menunjukkan potensinya dalam penggunaan pembungkusan makanan.
\end{abstract}

Kata kunci: Ciri fizikal; kanji; minyak kayu manis; sifat antimikrob

\section{ABSTRACT}

In this study, starch/cinnamon oil film was prepared by solution casting method with different concentrations of cinnamon oil (MKM) to study the effect of cinnamon oil on the antimicrobial properties of starch film. The transparency of the films was reduced with the increment of MKM. The transparency of the film was found to decrease as the percentage of MKM content increased which prevented light penetration. Meanwhile, ATR-FTIR analysis showed neither shifting of peak positions nor new peak formation which showed that MKM and starch film were not chemically bound. The antimicrobial studies of the films on Bacillus cereus and Aspergillus niger recorded the improvement of antimicrob activities with the addition of MKM with the increase of inhibition zone. It was found that inhibition at the minimum MKM concentration increased from 16\% in the starch film to a growth pattern in the zone of 24-44.2 mm in diameter with 28.23-37.88\% and 34.12-52\% increase in B. cereus and A. niger, respectively, compared to no inhibition zone for starch film without the addition of MKM. Morphological observations indicate pore formation and heterogeneous phase separation between MKM and starch. The maximum tensile strength of the film showed a decrease in tensile strength as the concentration of MKM increased despite not significant increase in MKM up to 24\%. On the other hand, strain at break was found to increase by 102-252\% in line with the addition of MKM acting as a plasticizing agent. In conclusion, starch/MKM films were successfully prepared and characterized. The physical and antimicrobial properties of the films displayed promising potential in food packaging application.

Keywords: Antimicrobial properties; cinnamon oil; physical properties; starch 


\section{PEngenalan}

Plastik berasaskan petroleum digunakan secara meluas dalam kehidupan manusia sejak berabad yang lalu kerana ketumpatannya yang rendah serta sifat mekanik dan fizikal yang tinggi (Dufresne et al. 2013). Walau bagaimanapun, isu peningkatan pencemaran alam sekitar yang disebabkan oleh plastik, terutamanya di negara membangun berada di tahap yang membimbangkan (Rosli et al. 2018). Plastik yang dihasilkan oleh petroleum tidak boleh terdegradasi dan hal ini telah menimbulkan masalah bagi proses pelupusannya berikutan penghasilan plastik yang berskala besar. Oleh sebab itu, plastik berasaskan biopolimer mula mendapat perhatian untuk menggantikan plastik konvensional sebagai alternatif plastik pembungkus sekaligus mengurangkan masalah pencemaran disebabkan pelupusan sisa (PlasticsEurope 2016).

Kanji adalah salah satu biopolimer semula jadi yang dikaji secara meluas untuk menghasilkan plastik yang terbiodegradasi. Penggunaan kanji telah mendapat perhatian penyelidik kerana kanji boleh terbiodegradasi, murah, banyak, senang didapati, tidak toksik dan boleh diperbaharui (Xie et al. 2013). Malah, filem kanji boleh diisi dengan pelbagai bahan aditif seperti agen antimikrob yang berguna dalam industri pembungkusan aktif bagi mengekalkan kualiti dan meningkatkan keselamatan makanan. Pembungkusan aktif dapat menjamin rasa asli dan ciri organoleptik makanan yang dibungkus dengan tempoh luput yang lebih lama, seterusnya dapat mengurangkan isu pembaziran makanan.

Konsep pembungkusan aktif ini semakin diterokai oleh industri makanan dan pembungkusan disebabkan beberapa kelebihannya berbanding penggunaan bahan pengawet secara terus ke dalam produk makanan (Siah et al. 2015). Kebiasaannya, pengawet sintetik digunakan bagi mengawal pertumbuhan mikroorganisma dalam makanan. Berikutan kesedaran pengguna tentang isu keselamatan penggunaan pengawet sintetik, penggunaan sebatian semula jadi seperti minyak pati mula mendapat perhatian. Minyak pati dilaporkan mempunyai aktiviti antimikrob terhadap pelbagai jenis patogen bawaan makanan dan dikategorikan sebagai 'Generally Recognized as Safe' (GRAS) oleh U.S. FDA (2009). Hal ini menunjukkan bahawa minyak pati boleh terus digunakan dalam industri makanan tanpa kelulusan FDA. Namun, penggunaan minyak pati secara terus ke dalam makanan berkemungkinan akan mengubah rasa sensori makanan. Bagi mengatasi masalah ini, minyak pati dimasukkan ke dalam filem polimer bagi tujuan pembungkusan makanan.

Kajian penambahan minyak pati ke dalam matrik polimer bagi memberi sifat antimikrob dan antioksida telah banyak dilakukan. Sebagai contoh, minyak kayu manis (MKM) dilaporkan menunjukkan kesan perencatan aktiviti antimikrob terhadap pelbagai jenis mikroorganisma (Chao et al. 2000). Malah, pembungkusan aktif bersama MKM telah menunjukkan keberkesanan dalam menambah jangka hayat beberapa makanan seperti pisang (Han et al. 2017), strawberi (Wen et al. 2016), jambu batu (Botelho et al. 2016), betik (Espitia et al. 2012), udang halus (Arancibia et al. 2014), ikan trout (Ojagh et al. 2010) dan daging khinzir (Hu et al. 2015).

Kerosakan makanan yang disebabkan oleh bakteria dan kulat bukan sahaja boleh menjejaskan rupa, rasa dan bau makanan tersebut, tetapi juga boleh menyebabkan keracunan makanan. Dalam kajian ini, dua jenis mikroorganisma dipilih iaitu Bacillus cereus dan Aspergillus niger yang boleh merosakkan makanan dan menjejaskan kesihatan manusia. Umumnya, Bacillus cereus adalah salah satu bakteria yang menyebabkan kerosakan makanan yang berasaskan kanji, beras, susu dan sayuran (Diao et al. 2018). Makanan yang telah tercemar dengan Bacillus boleh menyebabkan keracunan makanan dengan tanda-tanda seperti pening, muntah dan cirit-birit (Subhankulov \& Krainova 1979). Manakala Aspergillus niger adalah kulat yang senang membiak dan tersebar di kawasan yang beriklim panas. Spesies ini selalu menjadi punca kerosakan buah-buahan dan dilaporkan menghasilkan mikrotoksin dalam makanan (Pitt \& Hocking 2009).

Dalam kajian ini, aktiviti antimikrob filem kanji/MKM terhadap Bacillus cereus dan Aspergillus bransilensis telah dilakukan untuk mengkaji keberkesanan MKM sebagai bahan antimikrob. Objektif kajian ini adalah untuk mengkaji kesan penambahan MKM terhadap filem kanji dan melakukan pencirian fizikal, mekanik dan antimikrob filem tersebut.

\section{UJI KAJI}

\section{BAHAN}

Kanji ubi kayu (ABC Sdn. Bhd. Malaysia), minyak kayu manis, gliserol dan poli-sorbat 80 ataupun dikenali sebagai Tween 80 digunakan untuk menyediakan filem kanji/ MKM. MKM yang digunakan mempunyai ciri-ciri seperti berwarna kuning ke coklat gelap, indeks pembiasan n20/D 1.53 dan takat kilat pada $87^{\circ} \mathrm{C}$. Semua bahan kimia diperoleh daripada Sigma-Aldrich dan digunakan terus tanpa penulenan.

\section{KAEDAH}

Filem termoplastik kanji (TPS) disediakan melalui kaedah pengacauan larutan. Sebanyak $10 \mathrm{~g}$ kanji dicampurkan bersama $5 \mathrm{~g}$ gliserol sebagai agen pemplastikan dan dikacau di dalam $180 \mathrm{~g}$ air. Formulasi yang sama telah digunakan dalam kajian sebelum ini (Famá et al. 2006, 2005; Garcia et al. 2011). Campuran tersebut dipanaskan sehingga penggelatinan kanji terjadi. Dalam kajian ini, Tween 80 digunakan bagi memastikan MKM tersebar dengan lebih homogen; MKM dicampurkan dahulu dengan Tween 80 pada nisbah MKM: Tweeen 80 sebanyak 1:02. Seterusnya, bagi menyediakan filem antimikrob, MKM dicampurkan dengan kanji emulsi dengan kepekatan julat 4-32\% w/w. Filem kanji tanpa 
MKM turut disediakan sebagai sampel kawalan. Emulsi dituang ke atas plat perspek dan dikeringkan di dalam relau pada suhu $50{ }^{\circ} \mathrm{C}$ selama 24 jam. Akhir sekali, filem kanji disimpan di dalam kabinet kering selama 5 hari pada kelembapan relatif $30 \%$ dengan suhu $25^{\circ} \mathrm{C}$ sebelum analisis seterusnya dijalankan.

\section{PENCIRIAN}

Kehantaran cahaya filem diukur dengan menggunakan spektrofotometer UV-vis (Mettler Toledo) mengikut prosedur yang dicadangkan oleh Shiku et al. (2004). Nilai kelegapan (T) filem pula dihitung menggunakan formula berikut (Han \& Floros 1997):

$$
T=\frac{A_{600}}{x}
$$

dengan $\mathrm{A}_{600}$ adalah luas di bawah puncak penyerapan pada panjang gelombang $600 \mathrm{~nm}$ dan $\mathrm{x}$ adalah ketebalan filem ( $\mathrm{mm})$.

Kehadiran kumpulan berfungsi yang terdapat dalam filem dikenal pasti menggunakan spektrometer transformasi Fourier inframerah-pantulan penuh kecil (ATR-FTIR) (Perkin Elmer) pada julat nombor gelombang $650-4000 \mathrm{~cm}^{-1}$. Aktiviti antimikrob filem pula ditentukan menggunakan kaedah cerapan cakera terhadap Bacillus cereus dan Aspergillus niger. Morfologi permukaan filem dianalisis dengan menggunakan mikroskopi elekton imbasan pancaran (FESEM) model SYPRA 55VP (ZEISS). Sifat regangan filem dinilai menggunakan mesin ujian tegangan (Instron model 5566, USA) pada suhu bilik (25 ${ }^{\circ} \mathrm{C}$ ) berdasarkan protokol ASTM D882.

\section{KEPUTUSAN DAN PERBINCANGAN}

\section{SIFAT KELUTSINARAN}

Pemerhatian secara makroskopik jelas menunjukkan MKM memberi perubahan warna kepada filem kanji. Secara fizikal, filem kanji tanpa penambahan MKM adalah lutsinar dan jernih. Dengan penambahan MKM, warna jernih filem kanji menjadi semakin kekuningan (Rajah 1). Perubahan ketara ini disebabkan warna pigmen MKM yang kekuningan. Hal ini selari dengan kajian oleh Peng dan Li (2004) yang melaporkan peningkatan warna kekuningan yang ketara pada filem kitosan mereka selepas penambahan MKM sebanyak $0.01 \% \mathrm{v} / \mathrm{v}$. Selain itu, kajian filem alginat/MKM (Zhang et al. 2015), polilaktida/MKM (Ahmed et al. 2016), gelatin/MKM (Kim et al. 2018) menunjukkan trend perubahan warna yang sama.

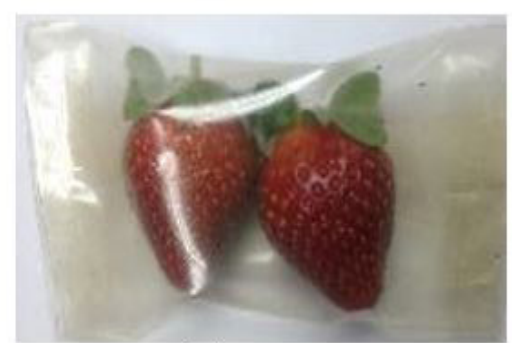

(a)

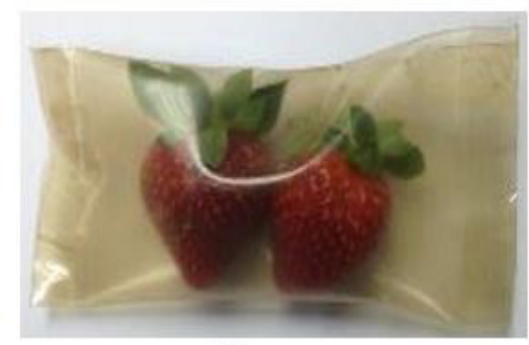

(b)

RAJAH 1. Perubahan warna filem kanji selepas penambahan MKM (a) filem kanji dan (b) filem kanji/MKM

Sifat optik adalah antara ciri yang penting dalam aplikasi filem khususnya bagi filem yang digunakan untuk menyalut permukaan makanan ataupun membungkus makanan. Kelegapan filem menunjukkan jumlah cahaya yang boleh menembusinya berdasarkan tahap kelutsinaran. Kelegapan filem ditentukan dengan mengukur kebolehan cahaya yang menembusi sampel untuk mendapatkan nilai kelegapan dengan nilai relatif kelegapan yang rendah menandakan bahawa filem lebih bersifat lutsinar (Han \& Floros 1997). Rajah 2 menunjukkan keputusan ujian kelegapan filem yang dibangunkan dalam kajian ini. Filem kanji tanpa
MKM mempunyai nilai kelegapan 0.63 , apabila MKM dengan kepekatan 4\% w/w dicampurkan ke dalam formulasi, kelegapan filem meningkat sebanyak 0.81 . Manakala kajian oleh Chu et al. (2019) terhadap filem pululan, kelegapan filem tanpa MKM adalah 0.52 tetapi meningkat kepada 0.6 apabila $4 \%$ w/w. MKM dicampurkan ke dalam filem.

Berdasarkan trend yang ditunjukkan dalam Rajah 2, didapati bahawa dengan penambahan MKM, kelegapan filem semakin meningkat tinggi apabila semakin kurang cahaya boleh menembusi filem. Hasil kajian ini berpadanan dengan kajian penambahan MKM yang 
lain ke dalam biopolimer seperti gelatin ikan ( $\mathrm{Wu}$ et al. 2017), PLA (Ahmed et al. 2016) dan kitosan (Peng \& Li 2014) yang menunjukkan bahawa kelegapan filem akan meningkat apabila kuantiti MKM dalam filem bertambah. Kajian oleh Amaral et al. (2019) terhadap filem kanji bersama minyak patio oren juga menunjukkan minyak pati oren meningkatkan kelegapan filem dengan peningkatan kepekatan minyak pati. Kelegapan meningkat yang disebabkan oleh minyak pati juga diperhatikan oleh Sánchez-González et al. (2009) dengan kajian terhadap filem HPMC dengan minyak tea tree.

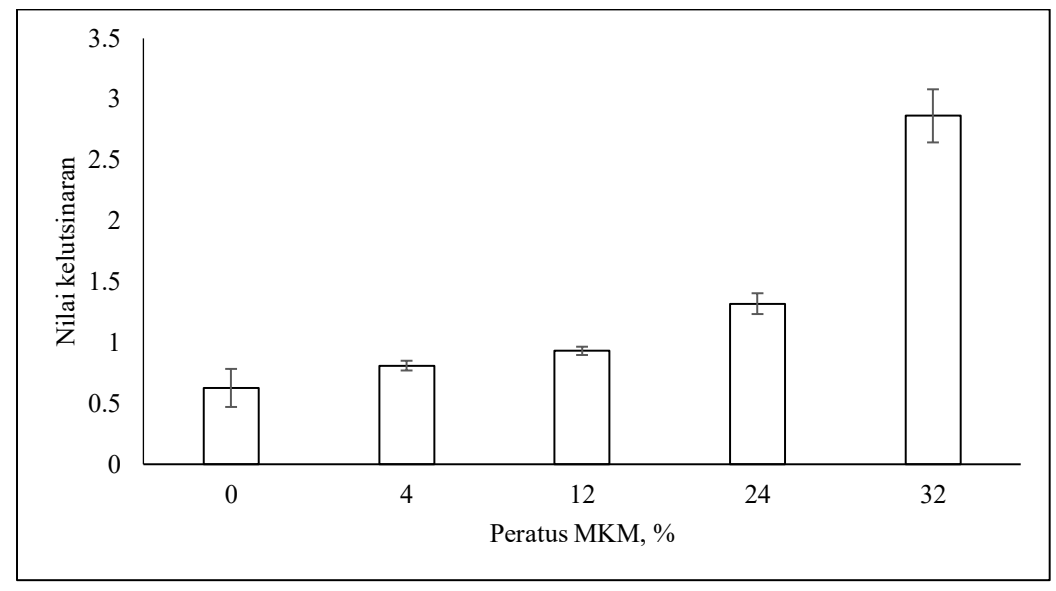

RAJAH 2. Trend penambahan peratus MKM terhadap nilai kelutsinaran

Hasil kajian menunjukkan bahawa penambahan minyak pati ke dalam formulasi filem meningkatkan kelegapan filem dan menyebabkan ketelusan filem menjadi semakin berkurangan. Fenomena ini terjadi kerana penambahan minyak pati menyebabkan titisan MKM di dalam matrik menghalang kehantaran cahaya dan menyebabkan serakan cahaya. Selain itu, indeks pembiasan filem juga berubah disebabkan kehadiran minyak pati (Atares \& Chiralt 2016; Valencia-sullca et al. 2017). Kandungan MKM yang bertambah dalam filem telah mengurangkan ketelusan filem dan mengganggu jaringan mikrostruktur filem (Song et al. 2018; Wu et al. 2017) disebabkan serakan cahaya yang bergantung kepada saiz zarah dalam fasa sebaran (Shamsuri et al. 2009; Wu et al. 2017). Hal ini menunjukkan bahawa minyak pati mempunyai kesan ke atas penampilan dan sifat kehantaran cahaya ke atas filem yang dihasilkan.

\section{SPEKTROSKOPI FTIR}

Analisis FTIR dijalankan bagi mengetahui interaksi filem kanji dengan MKM. Rajah 3 membandingkan spektrum FTIR bagi MKM, sampel filem kawalan dan filem kanji/ MKM. Terdapat pertindihan penyerapan bagi pelbagai komponen yang terkandung dalam MKM. Spektrum tipikal MKM telah dikesan seperti $1718 \mathrm{~cm}^{-1}$ (aldehid lemak tepu), $1671 \mathrm{~cm}^{-1}$ dan $1638 \mathrm{~cm}^{-1}$ (getaran regangan karbonil aldehid $\mathrm{C}=\mathrm{O}$ ). Puncak spektrum ini berpadanan dengan sinamaldehid dan aldehid dalam MKM. Puncak pada $1511 \mathrm{~cm}^{-1}$ menunjukkan getaran gelang rangka $\mathrm{C}=\mathrm{C}$ dalam bahan aromatik. Puncak $1232 \mathrm{~cm}^{-1}$ pula mewakili pengembangan simetrik ester asid aromatik C-O-C dan getaran regangan kumpulan fenolik $\mathrm{C}-\mathrm{OH}$, yang menunjukkan ciri serapan ester dan eugenol dalam MKM (Li et al. 2013).

Filem kanji menunjukkan regangan intermolekul dan intramolekul ikatan kumpulan hidroksil kanji pada 3200-3400 $\mathrm{cm}^{-1}$ (Sessini et al. 2016). Puncak ini jugak boleh merujuk kepada regangan kumpulan $\mathrm{OH}$ daripada gliserol dan air (Jaramillo et al. 2016; Seligra et al. 2016). Puncak seperti $2893 \mathrm{~cm}^{-1}$ dan $2925 \mathrm{~cm}^{-1}$ mewakili getaran regangan $\mathrm{C}-\mathrm{H}, 1078 \mathrm{~cm}^{-1}$ (getaran regangan $\mathrm{C}-\mathrm{O}-\mathrm{H}$ ) dan $1016 \mathrm{~cm}^{-1}$ (getaran regangan C-O-C) (Ahmed et al. 2018; Dumoulin et al. 1998; Jiugao \& Ning 2005). Puncak pada 926, 860 dan $760 \mathrm{~cm}^{-1}$ juga menunjukkan konfigurasi $\alpha$ bagi ikatan glikosidik yang tipikal bagi kanji (Capek et al. 2010; Dankar et al. 2018; Sheng et al. 2018).

Selepas penambahan MKM, spektrum FTIR kanji/ MKM masih menunjukkan serapan dominan untuk filem kanji. Pencirian serapan puncak ikatan glikosidik C-O-C pada $1150 \mathrm{~cm}^{-1}$ adalah sama bagi kesemua filem kanji kawalan dan filem kanji/MKM. Hal ini menunjukkan bahawa panjang rantaian glikosidik tidak diubah suai oleh MKM. Puncak sekitar $1648 \mathrm{~cm}^{-1}$ yang merujuk kepada serapan sensitif ikatan hidrogen dan jumlah interaksi hidroksil juga tidak menunjukkan perubahan sebagaimana puncak ikatan glikosidik C-O-C. Hal ini jelas 
menunjukkan bahawa penambahan MKM ke dalam filem kanji tidak mengubah ikatan kimia kanji. Penemuan yang sama juga dilaporkan dalam kajian filem kanji/rosemary (Piñeros-Hernandez et al. 2017) dan filem kanji/yerba mate (Jaramillo et al. 2016) apabila ekstrak minyak pati bahan yang dimasukkan tidak mengubah struktur kimia filem kanji tersebut.

Walau bagaimanapun, kepekatan MKM yang lebih tinggi iaitu 24 dan 32\% menunjukkan pertambahan puncak pada $1511 \mathrm{~cm}^{-1}$ yang merujuk kepada puncak MKM. Trend yang sama berlaku untuk filem kanji bersama minyak rosemary (Piñeros-Hernandez et al.
2017) dan filem poliasid laktik/MKM (Ahmed et al. 2016) apabila keamatan puncak yang kecil diperhatikan pada sekitar $1511 \mathrm{~cm}^{-1}$ yang mewakili domain aromatik minyak pati. Sementara itu, tiada penyesaran puncak yang bererti diperhatikan dalam spektrum filem kanji/ MKM berbanding spektrum MKM tulen. Keamatan interaksi MKM dengan kanji yang lemah tidak mampu mengubah suai corak regangan kumpulan molekul dalam filem. Interaksi Van der Waals dan interaksi hidrofobik antara MKM dan rantaian kanji boleh dicadangkan bagi menjelaskan keadaan ini (Muller et al. 2017).

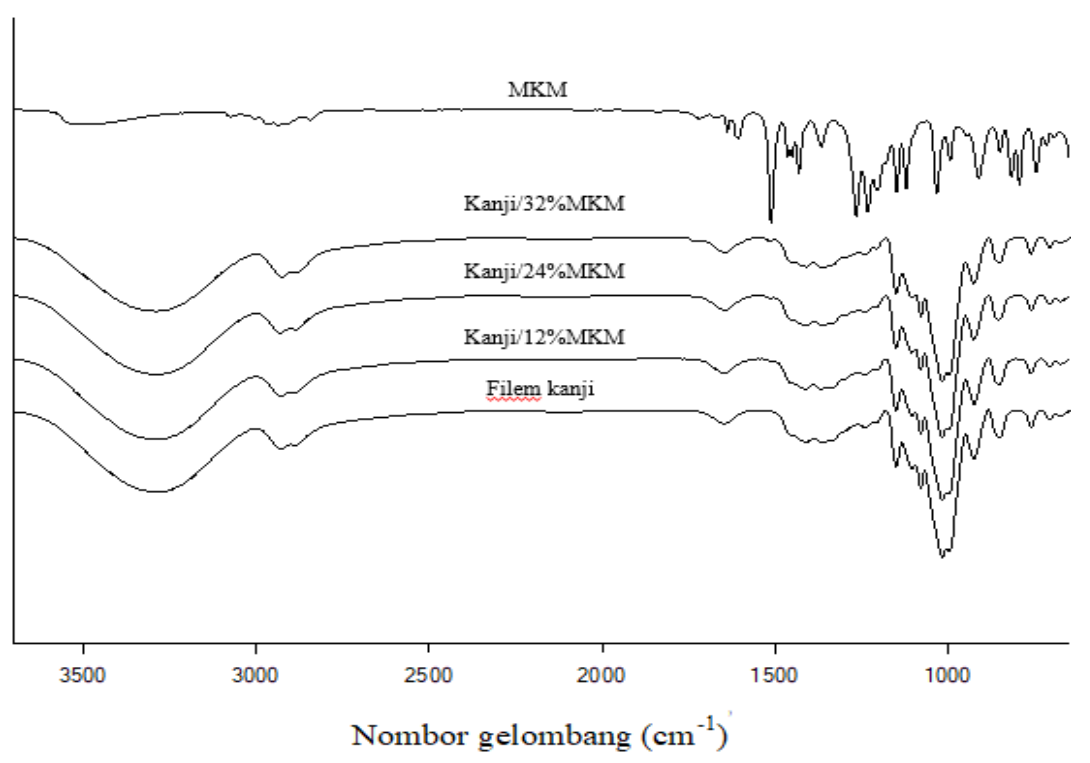

RAJAH 3. Spektrum FTIR bagi filem kanji bersama komposisi MKM yang berbeza

\section{SIFAT ANTIMIKROB}

Sifat antimikrob filem kanji dan kanji bersama MKM terhadap bakteria Bacillus cereus dan kulat Aspergillus niger ditentukan melalui kaedah ujian serapan cakera. Aktiviti perencatan bergantung kepada saiz zon perencatan yang jelas di sekeliling cakera filem. Keputusan dan data analisis aktiviti antimikrob ini boleh dilihat pada Rajah 4 dan Jadual 1.

Seperti yang dijangka, filem kawalan tidak menunjukkan sebarang zon perencatan bagi kedua-dua mikroorganisma. Tambahan pula, permukaan sentuh filem kanji dengan kedua-dua mikroorganisma juga adalah negatif apabila $B$. cereus dan $A$. niger dapat tumbuh atau merebak di atas filem. Hal ini menunjukkan bahawa filem kanji tanpa MKM tidak mempunyai sebarang aktiviti antimikrob terhadap kedua-dua bakteria dan kulat. Kajian oleh Ali et al. (2018) dan Oriani et al. (2014) juga melaporkan bahawa filem kanji tanpa penambahan agen antimikrob seperti minyak pati tidak mampu merencat patogen seperti Staphlococus, Esherichia dan Salmonella.

Penambahan MKM pada 4 dan 8\% memberi kesan antimikrob dengan pengurangan pertumbuhan mikrooganisma pada permukaan filem. Walaupun tiada zon perencatan pada filem kanji/12\% MKM, tetapi wujud kesan perencatan pada permukaan sentuh filem untuk kedua-dua mikrob. Formulasi di bawah $12 \%$ w/w MKM pula tidak dapat melindungi filem kanji itu sendiri daripada serangan mikroorganisma.

Umumnya, diameter zon perencatan semakin bertambah besar dengan meningkatnya agen antimikrob atau minyak pati. Kecekapan aktiviti antimikrob bagi penambahan MKM pada kepekatan minimum 16\% w/w dalam filem kanji meningkat daripada 28.23-37.88\% dan $34.12-52 \%$, masing-masing bagi zon perencatan 
terhadap $B$. cereus dan $A$. niger di dalam piring Petri 85 mm. Xing et al. (2014) mendapati kesan antikulat MKM pada kepekatan serendah 20 dan $30 \mu \mathrm{L}$ untuk setiap piring Petri $(90 \mathrm{~mm})$. Kajian oleh Amaral et al. (2019) juga mendapati bahawa apabila minyak pati oren ditambah ke dalam filem kanji, kepekatan minyak oren masingmasing pada $0.3,0.5$ dan $0.7 \mu \mathrm{L} / \mathrm{g}$ telah mengurangkan pertumbuhan Listeria monocytogenes sebanyak 68, 80 dan $83 \%$. Dalam kajian ini, sifat antimikrob filem kanji/ MKM didapati semakin bertambah dengan pertambahan kepekatan MKM.

Bullermen et al. (1977) melaporkan bahawa komponen utama MKM iaitu sinamik aldehid merencat pertumbuhan dan penghasilan toksin Aspergillus parasiticus. Manakala kajian oleh Xing et al. (2014) pula menjelaskan bahawa kesan perencatan MKM terhadap Fusarium verticillioides adalah berkadar terus dengan kepekatan sinamaldehid. Perencatan pertumbuhan kulat tersebut juga menyebabkan perubahan morfologi dan ultrastruktur kulat yang tidak berbalik.

Mekanisma tindakan MKM terhadap bakteria khususnya terjadi dengan kerosakan sel, penyahaktifan enzim dan pemusnahan bahan genetik (Oussalah et al. 2006). Wendakoon dan Sakagutchi (1995) melaporkan bahawa kumpulan berfungsi hidroksil pada eugenol terikat pada protein yang menghalang aktiviti enzim dalam Enterobacter aerogenes, manakala sinamaldehid merencat aktiviti enzim dekarboksilase. Oleh sebab MKM mempunyai komposisi molekul yang berbezabeza, mekanisma tindak balas MKM adalah bergantung kepada tindak balas setiap komponen secara individu ke atas sasaran sel yang khusus dan juga kesan sinergestik kesemua sebatian (Afandi et al. 2017).

\begin{tabular}{|c|c|c|c|}
\hline Mikroorganisma & $0 \% \mathrm{MKM}$ & $12 \% \mathrm{MKM}$ & $32 \% \mathrm{MKM}$ \\
\hline Bacillus cereus & & & \\
\hline Aspergillus niger & & & \\
\hline
\end{tabular}

RAJAH 4. Zon perencatan filem kanji dengan kandungan MKM berbeza

JADUAL 1. Aktiviti antimikrob filem kanji dengan kepekatan MKM yang berbeza terhadap B. cereus dan A. niger

\begin{tabular}{lcc}
\hline Kepekatan MKM & $\begin{array}{c}\text { B. cereus } \\
\text { Zon perencatan }(\mathrm{mm})\end{array}$ & $\begin{array}{c}\text { A. Niger } \\
\text { Zon perencatan }(\mathrm{mm})\end{array}$ \\
\hline 0 (kawalan) & $0.0(-)$ & $0.0(-)$ \\
4 & $0.0(-)$ & $0.0(-)$ \\
8 & $0.0(-)$ & $0.0(-)$ \\
12 & $0.0(+)$ & $0.0(+)$ \\
16 & $24.0(+)$ & $29.0(+)$ \\
24 & $28.0(+)$ & $39.0(+)$ \\
28 & $30.0(+)$ & $41.8(+)$ \\
32 & $32.2(+)$ & $44.2(+)$ \\
\hline
\end{tabular}




\section{SIFAT REGANGAN}

Ujian tegangan telah dijalankan bagi mengkaji sifat regangan filem kanji/MKM yang terhasil. Rajah 5 menunjukkan trend perubahan sifat mekanik filem (tegangan maksimum dan terikan pada takat putus) dengan kepekatan MKM.

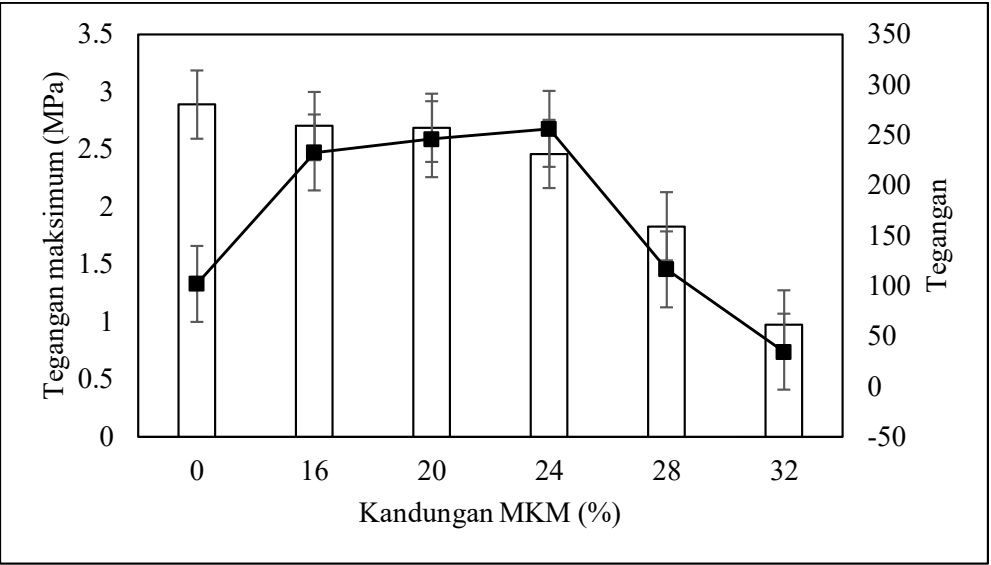

RAJAH 5. Sifat mekanik filem kanji/MKM

Keputusan menunjukkan berlaku penurunan nilai tegangan maksimum bagi filem kanji-minyak kayu manis berbanding filem kanji. Walau bagaimanapun, penurunan tegangan ini tidak begitu signifikan pada peratusan MKM antara 16-24\% w/w. Keputusan yang sama turut dilaporkan oleh Wu et al. (2017), dalam kajian terhadap filem gelatin dengan penambahan 0.5-6\% MKM juga mendapati penurunan pada tegangan maksimum. Trend yang sama turut dilaporkan oleh Tongnuanchan et al. (2016). Penurunan tegangan maksimum filem tersebut adalah disebabkan penggantian interaksi polimer-polimer yang lebih kuat kepada ikatan polimerminyak yang lebih lemah pada jaringan filem. Hal ini akan melemahkan struktur jaringan dan menyebabkan pengurangan kekuatan tegangan ( $\mathrm{Li}$ et al. 2018; Tongnuanchan et al. 2015).

Sementara itu, takat putus pula menunjukkan pola peningkatan daripada $102 \%$ kepada $252 \%$ dengan peningkatan kepekatan MKM bagi 0 hingga 24\% w/w. Hasil kajian Ghasemlou et al. (2013) terhadap filem kanji jagung menunjukkan bahawa peningkatan minyak Zataria multiflora Boiss dan minyak Mentha pulegium daripada 2 ke 3\%, masing-masing meningkatkan pemanjangan pada takat putus sebanyak 94.38$162.45 \%$ dan 53.34-107.71\%. Ghasemlou et al. (2013) mendapati bahawa keregangan filem karagenan adalah disebabkan oleh penambahan minyak Stureja hortensis yang bertindak sebagai agen pemplastikan walaupun pada kepekatan yang rendah. Menurut Han et al. (2017) pula, kehadiran MKM akan mengurangkan daya lekitan jaringan polimer dan meningkatkan pergerakan filem. Hasil kajian ini adalah konsisten dengan kajian terdahulu yang merekodkan peningkatan terikan pada takat putus dengan penambahan minyak pati ke dalam formulasi filem (Sánchez-González et al. 2009; Wu et al. 2017).

Walau bagaimanapun, terikan pada takat putus menurun bermula pada $28 \% \mathrm{w} / \mathrm{w}$ MKM. Penurunan pada kandungan minyak kayu manis yang tinggi ini disebabkan pembentukan ketakselanjaran natrium alginat yang berlebihan lalu menyebabkan pengurangan rintangan mekanik filem. Trend perubahan yang sama juga diperoleh dalam kajian Han et al. (2017) apabila terikan pada takat putus mula menurun dengan penambahan $15 \mathrm{~g} / \mathrm{L}$ MKM ke dalam filem natrium alginat/MKM. Ma et al. (2015) juga melaporkan bahawa pada kepekatan minyak pati yang tinggi, ketercanggaan filem akan berkurang dan menyebabkan peningkatan keretakan dan pengurangan keregangan.

\section{PEMERIKSAAN MORFOLOGI}

Filem kanji mempunyai morfologi permukaan atas dan bahagian patah yang licin, struktur yang padat dan seragam tanpa rekahan atau liang (Rajah 6). Permukaan kanji juga tidak mengandungi granul yang menandakan bahawa penggelatinan semasa pemprosesan termal berlaku secara lengkap (Muller et al. 2017). Keputusan ATR-IR yang telah direkodkan menunjukkan bahawa tiada interaksi kimia berlaku antara matrik dan MKM. Hal ini dapat dibuktikan melalui morfologi pemisahan fasa filem yang semakin ketara terbentuk apabila kepekatan MKM meningkat. Pemisahan fasa ini menyebabkan pemindahan beban antara fasa terhalang sekaligus menyebabkan kegagalan kesan nyah ikatan antara muka (Young et al. 2000) lalu menyebabkan berlakunya penurunan pada nilai tegangan maksimum. 
Permukaan atas filem kanji yang mengandungi MKM tidak menunjukkan perbezaan yang ketara dengan permukaan atas filem kanji, kecuali pada $32 \% \mathrm{w} / \mathrm{w}$ MKM apabila terdapat lebih banyak liang yang menunjukkan kandungan MKM berlebihan. Menurut Wang et al. (2011) dalam kajian mereka terhadap filem kitosan/minyak cengkih, titisan minyak dengan saiz 5 - $20 \mu$ muncul pada permukaan filem. Hal tersebut menunjukkan bahawa minyak cengkih adalah tidak serasi bersama molekul kitosan lalu mewujudkan pemisahan fasa. Selain itu, penambahan MKM ke dalam filem PLA/PEG telah menjadikan produk filem yang kasar dengan liang yang ketara (Ahmed et al. 2016).

Kebanyakan kajian menunjukkan bahawa semakin tinggi pertambahan minyak pati dalam formulasi filem, permukaan patah filem akan menjadi lebih heterogen. Filem kanji dengan kepekatan yang tinggi $(32 \% \mathrm{w} / \mathrm{w}$ MKM) mula menunjukkan kehadiran liang yang lebih ketara pada permukaan patah filem yang merujuk kepada titisan lipid terbenam dalam filem kanji/MKM (Jouki et al. 2014). Pertambahan kepekatan MKM iaitu sebanyak $32 \% \mathrm{w} / \mathrm{w}$ telah menyebabkan liang dalam filem menjadi semakin besar disebabkan oleh pengagregatan dan tautan minyak dalam filem (Sánchez-gonzález et al. 2010).

Hasil kajian oleh Amaral et al. (2019) terhadap filem kanji juga menunjukkan bahawa minyak pati oren mengurangkan kehomogenan filem apabila morfologi pada keratan rentas filem didapati mengandungi banyak liang pada permukaannya. Han et al. (2018) yang menyediakan filem natrium alginat/MKM turut melaporkan penemuan yang sama. Sifat hidrofobik filem dan perbezaan ketumpatan minyak dengan larutan akues kanji mempengaruhi kestabilan larutan filmogenik yang akan menyebabkan struktur yang lebih heterogen dengan kehadiran liang (Zainuddin et al. 2017).

Tambahan pula, sifat heterogen filem ini membantu proses resapan minyak pati dari bahagian dalaman polimer ke permukaan luaran matrik polimer. Hal ini bertepatan dengan objektif penyelidikan yang ingin memberi sifat antimikrob minyak pati kepada filem. Hal ini dapat dibuktikan apabila filem dengan liang yang lebih ketara menunjukkan zon perencatan yang lebih baik.

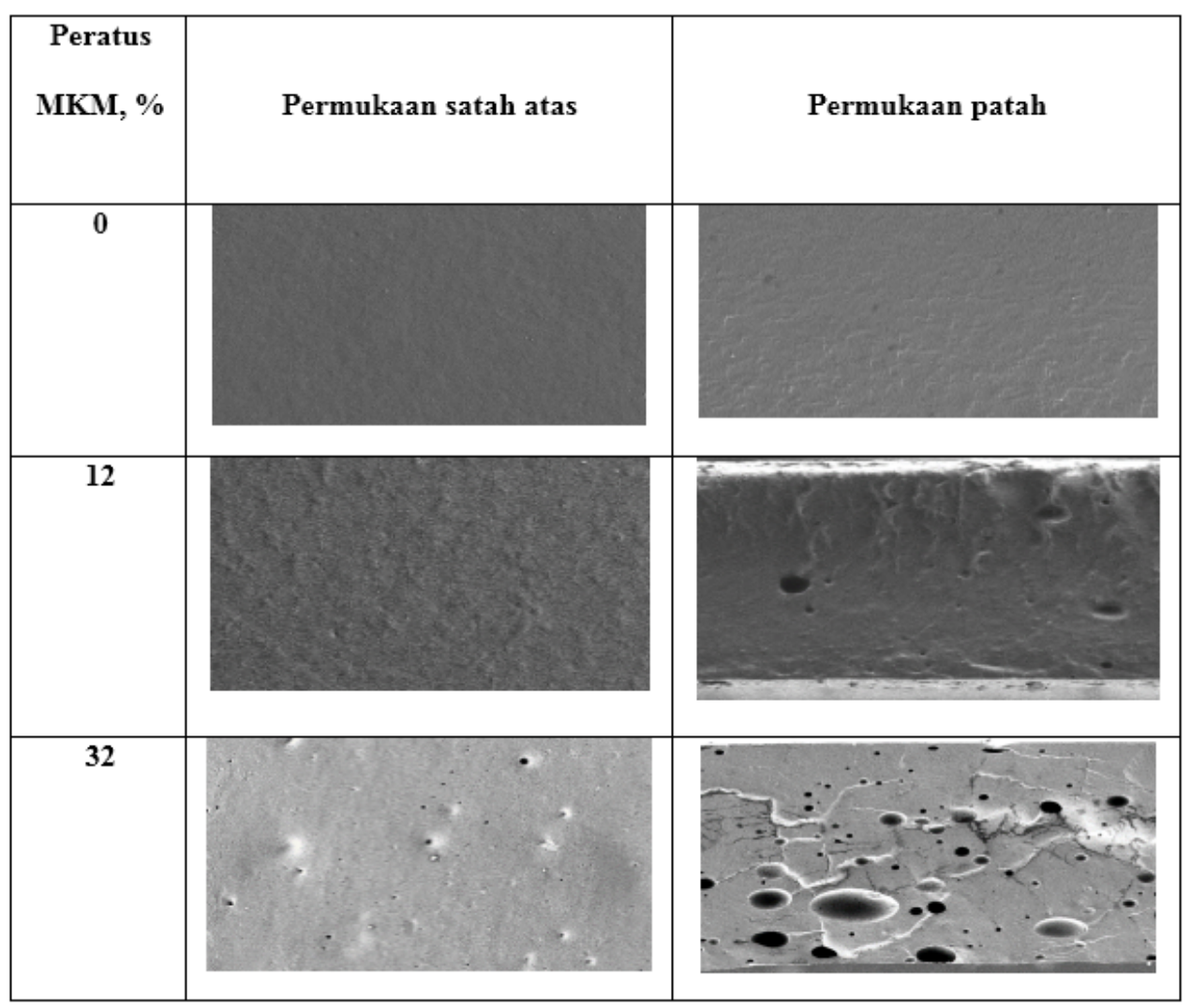

RAJAH 6. Mikrograf FESEM bagi filem kanji/MKM 


\section{KESIMPULAN}

Filem kanji/MKM telah berjaya disediakan melalui kaedah pengacauan larutan. Nilai kelutsinaran filem didapati bertambah apabila peratus MKM bertambah yang menunjukkan pertambahan sifat kelegapan filem. Analisis FTIR menunjukkan bahawa tiada interaksi ikatan kimia terbentuk antara kanji dan MKM. Penambahan MKM didapati telah memberi kesan antimikrob dengan pengurangan pertumbuhan mikrooganisma pada permukaan filem. Peningkatan minyak kayu manis didapati berlaku sedikit penurunan kekuatan filem walaupun tidak begitu ketara hingga $24 \%$ w/w MKM namun berjaya meningkatkan kefleksibelan filem tersebut. Secara keseluruhannya, filem kanji/MKM berpotensi dijadikan sebagai filem pembungkus makanan kerana mempunyai sifat antimikrob dan mekanik yang baik.

\section{PENGHARGAAN}

Penulis ingin berterima kasih kepada Universiti Kebangsaan Malaysia (UKM) atas geran penyelidikan MI-2019-020 yang diberikan dan Center for Research dan Instrumentation (CRIM), UKM bagi kemudahan instrumentasi.

\section{RUJUKAN}

Afandi, A., Lazim, A.M., Azwanida, N.N., Bakar, M.A., Airianah, O.B. \& Fazry, S. 2017. Antibacterial properties of crude aqueous Hylocereus polyrhizus peel extracts in lipstick formulation against gram-positive and negative bacteria. Malaysian Applied Biology 46(2): 29-34.

Ahmed, A.J., Thomas, L. \& Arfat, Y.A. 2018. Rheological, structural and functional properties qunoa starch. Carbohydrate Polymers 116: 302-311.

Ahmed, J., Mulla, M.Z. \& Arfat, Y.A. 2016. Thermo-mechanical, structural characterization and antibacterial performance of solvent casted polylactide/cinnamon oil composite films. Food Control 69: 196-204.

Ali, A., Chen, Y., Liu, H., Yu, L., Khalid, S., Zhu, J. \& Chen, L. 2018. Starch-based antimicrobial films functionalized by pomegranate peel. International Journal of Biological Macromolecules 60(19): 4841-4848.

Amaral, J., Dannenberg, S., Biduski, B., Lisie, S., Hüttner, D., Arocha, M. \& Maria, A. 2019. Antibacterial activity, optical, mechanical and barrier properties of corn starch films containing orange essential oil. Carbohydrate Polymer 222: 114981

Arancibia, M., Giménez, B., López-Caballero, M.E., GómezGuillén, M.C. \& Montero, P. 2014. Release of cinnamon essential oil from polysaccharide bilayer films and its use for microbial growth inhibition in chilled shrimps. $L W T$ Food Science and Technology 59(2): 989-995.

Atares, L. \& Chiralt, A. 2016. Essential oils as additives in biodegradable films and coatings for active packaging. Trends in Food Science \& Technology 48: 51-62.

Botelho, L.N.S., Rocha, D.A., Braga, M.A., Silva, A. \& de Abreu, C.M.P. 2016. Quality of guava cv. "Pedro Sato" treated with cassava starch and cinnamon essential oil. Scientia Horticulturae 209: 214-220.
Bullerman, L.B., Lieu, F.Y. \& Seier, S.A. 1977. Inhibition of growth and aflatoxin production by cinnanamon and clove oils. Cinnamic aldehyde and eugenol. Journal of Food Science 42(4): 1107-1109.

Capek, P., Drábik, M. \& Turjan, J. 2010. Characterization of starch and its mono and hybrid derivatives by thermal analysis and FT-IR spectroscopy. Journal of Thermal Analysis and Calorimetry 99(2): 667-673.

Chao, S.C., Young, D.G. \& Oberg, C.J. 2000. Screening for inhibitory activity of essential oils on selected bacteria, fungi and viruses screening for inhibitory activity of essential oils on selected bacteria, fungi and viruses. Journal of Essential Oil Research 12(5): 37-41.

Chu, Y., Xu, T., Gao, C., Liu, X., Zhang, N., Feng, X., Liu, X., Shen, X. \& Tang, X. 2019. Evaluations of physicochemical and biological properties of pullulan-based fi $1 \mathrm{~ms}$ incorporated with cinnamon essential oil and Tween 80 . International Journal of Biological Macromolecules 122: 388-394.

Dankar, I., Haddarah, A., Omar, F.E., Pujolà, M. \& Sepulcre, F. 2018. Characterization of food additive-potato starch complexes by FTIR and X-ray diffraction. Food Chemistry 260: 7-12.

Diao, M., Qi, D., Xu, M., Lu, Z., Lv, F., Bie, X. \& Zhao, H. 2018. Antibacterial activity and mechanism of monolauroylgalactosylglycerol against Bacillus cereus. Food Control 85: 339-344.

Dufresne, A., Thomas, S. \& Pothan, L.A. 2013. Biopolymer Nanocomposites. New Jersey: John Wiley \& Sons.

Dumoulin, Y., Alex, S., Szabo, P., Cartilier, L. \& Alexandru, M. 1998. Cross-linked amylose as matrix for drug controlled release. X-ray and FT-IR structural analysis. Carbohydrate Polymers 37(4): 361-370.

Espitia, P., Soares, N., Botti, L., Melo, N.R., Pereira, O. \& Silwa, W. 2012. Assessment of the efficiency of essential oils in the preservation of postharvest papaya in antimicrobial packaging systerm. Brazillian Journal of Food Technology 15(4): 332-342.

Famá, L., Flores, S.K., Gerschenson, L. \& Goyanes, S. 2006. Physical characterization of cassava starch biofilms with special reference to dynamic mechanical properties at low temperatures. Carbohydrate Polymers 66(1): 8-15.

Famá, L., Rojas, A.M., Goyanes, S. \& Gerschenson, L. 2005. Mechanical properties of tapioca-starch edible films containing sorbates. LWT - Food Science and Technology 38(6): 631-639.

Garcia, N.L., Ribba, L., Dufresne, A., Aranguren, M. \& Goyanes, S. 2011. Effect of glycerol on the morphology of nanocomposites made from thermoplastic starch and starch nanocrystals. Carbohydrate Polymers 84(1): 203-210.

Ghasemlou, M., Aliheidari, N., Fahmi, R. \& Shojaee-aliabadi, S. 2013. Physical, mechanical and barrier properties of corn starch films incorporated with plant essential oils. Carbohydrate Polymers 98(1): 1117-1126.

Han, J.H. \& Floros, J.D. 1997. Casting antimicrobial packaging films and measuring their physical properties and antimicrobial activity. Journal of Plastic Film \& Sheeting 13(4): 287-298.

Han, Y., Yu, M. \& Wang, L. 2018. Physical and antimicrobial properties of sodium alginate/carboxymethyl cellulose films incorporated with cinnamon essential oil. Food Packaging and Shelf Life 15(11): 35-42. 
Han, Y., Yu, M. \& Wang, L. 2017. Physical and antimicrobial properties of sodium alginate/carboxymethyl cellulose films incorporated with cinnamon essential oil. Food Packaging and Shelf Life 11: 1-8.

Hu, J., Wang, X., Xiao, Z. \& Bi, W. 2015. Effect of chitosan nanoparticles loaded with cinnamon essential oil on the quality of chilled pork. LWT - Food Science and Technology 63(1): 519-526.

Jaramillo, C.M., Gutiérrez, T.J., Goyanes, S., Bernal, C. \& Famá, L. 2016. Biodegradability and plasticizing effect of yerba mate extract on cassava starch edible films. Carbohydrate Polymers 151: 150-159.

Jiugao, Y. \& Ning, W. 2005. The effects of citric acid on the properties of thermoplastic starch plasticized by glycerol. Starch - Stärke 57(10): 494-504.

Jouki, M., Mortazavi, S.A., Yazdi, F.T. \& Koocheki, A. 2014. Characterization of antioxidant-antibacterial quince seed mucilage films containing thyme essential oil. Carbohydrate Polymers 99: 537-546.

Kim, H., Beak, S.E. \& Song, K.B. 2018. Development of a hag fish skin gelatin film containing cinnamon bark essential oil. LWT - Food Science and Technology 96(5): 583-588.

Li, J., Ye, F., Lei, L. \& Zhao, G. 2018. Combined effects of octenylsuccination and oregano essential oil on sweet potato starch films with an emphasis on water resistance. International Journal of Biological Macromolecules 115: 547-553.

Li, Y., Kong, D. \& Wu, H. 2013. Analysis and evaluation of essential oil components of cinnamon barks using GC - MS and FTIR spectroscopy. Industrial Crops and Products 41: 269-278.

Ma, Q., Zhang, Y., Critzer, F., Davidson, P.M., Zivanovic, S. \& Zhong, Q. 2015. Physical, mechanical, and antimicrobial properties of chitosan films with microemulsions of cinnamon bark oil and soybean oil. Food Hydrocolloids 52: $533-542$

Muller, J., González-martínez, C. \& Chiralt, A. 2017. Polylactic acid (PLA) and starch bilayer films, containing cinnamaldehyde, obtained by compression moulding. European Polymer Journal 95(7): 56-70.

Ojagh, S.M., Rezaei, M., Razavi, S.H. \& Hosseini, S.M.H. 2010. Effect of chitosan coatings enriched with cinnamon oil on the quality of refrigerated rainbow trout. Food Chemistry 120(1): 193-198.

Oriani, V.B., Molina, G., Chiumarelli, M., Pastore, G.M. \& Hubinger, M.D. 2014. Properties of cassava starch-based edible coating containing essential oils. Journal of Food Science 79(2): 189-194.

Oussalah, M., Caillet, S. \& Lacroix, M. 2006. Mechanism of action of Spanish oregano, Chinese cinnamon, and savory essential oils against cell membranes and walls of Esherichia coli O157:H7 and Listeria monocytogenes. Journal of Protection 69(5): 1046-1055.

Peng, Y. \& Li, Y. 2014. Food hydrocolloids combined effects of two kinds of essential oils on physical, mechanical and structural properties of chitosan films. Food Hydrocolloids 36: 287-293.

Phan, T.D., Peroval, C., Debeaufort, F., Despre, D., Courthaudon, J.L. \& Voilley, A. 2002. Arabinoxylan-lipid-based edible films and coatings. Influence of drying temperature on film structure and functional properties. Journal of Agricultural and Food Chemsitry 50: 2423-2428.
Piñeros-Hernandez, D., Medina-Jaramillo, C., López-Córdoba, A. \& Goyanes, S. 2017. Edible cassava starch films carrying rosemary antioxidant extracts for potential use as active food packaging. Food Hydrocolloids 63: 488-495.

Pitt, J.I. \& Hocking, A.D. 2009. Fungi and Food Spoilage. New York: Springer.

PlasticsEurope 2016. An analysis of European plastics production, demand and wate data. Plastic-The Facts. Association of Plastics Manufactures.

Rosli, N.A., Ahmad, I, Anuar, F.H. \& Abdullah, I. 2018. The contribution of eco-friendly bio-based blends on enhancing the thermal stability and biodegradability of poly(lactic acid). Journal of Cleaner Production 198: 987-995.

Sánchez-gonzález, L., González-martínez, C., Chiralt, A. \& Cháfer, M. 2010. Physical and antimicrobial properties of chitosan - tea tree essential oil composite films. Journal of Food Engineering 98: 443-452.

Sánchez-González, L., Vargas, M., González-Martínez, C., Chiralt, A. \& Cháfer, M. 2009. Characterization of edible films based on hydroxypropylmethylcellulose and tea tree essential oil. Food Hydrocolloids 23(8): 2102-2109.

Seligra, P.G., Medina Jaramillo, C., Famá, L. \& Goyanes, S. 2016. Biodegradable and non-retrogradable eco-films based on starch-glycerol with citric acid as crosslinking agent. Carbohydrate Polymers 138: 66-74.

Sessini, V., Arrieta, M.P., Kenny, J.M. \& Peponi, L. 2016. Processing of edible films based on nanoreinforced gelatinized starch. Polymer Degradation and Stability 132: 157-168.

Shamsuri, A.A., Daik, R., Ahmad, I. \& Jumali, M.H.H. 2009. Nylon-6/liquid natural rubber blends prepared via emulsion dispersion. Journal of Polymer Research 16(4): 381-387.

Sheng, L., Li, P., Wu, H., Liu, Y., Han, K.E., Gouda, M., Tong, Q., Ma, M. \& Jin, Y. 2018. Tapioca starch-pullulan interaction during gelation and retrogradation. LWT - Food Science and Technology 96(5): 432-438.

Shiku, Y., Hamaguchi, P.Y., Benjakul, S., Visessanguan, W. \& Tanaka, M. 2004. Effect of surimi quality on properties of edible films based on Alaska pollack. Food Chemistry 86: 493-499.

Siah, W.M., Abdullah, A. \& Ahmad, I. 2015. Edible films from seaweed (Kappaphycus alvarezii). International Food Research Journal 22(6): 2230-2236.

Song, X., Zuo, G. \& Chen, F. 2018. Effect of essential oil and surfactant on the physical and antimicrobial properties of corn and wheat starch films. International Journal of Biological Macromolecules 107: 1302-1309.

Subhankulov, M.A. \& Krainova, L.I. 1979. Properties and production characteristics of vomiting, diarrheal, and necrotizing toxins of $B$. cereus. American Journal of Clinical Nutrition 32(1): 219-228.

Tongnuanchan, P., Benjakul, S., Prodpran, T., Pisuchpen, S. \& Osako, K. 2016. Mechanical, thermal and heat sealing properties of fish skin gelatin film containing palm oil and basil essential oil with different surfactants. Food Hydrocolloids 56: 93-107.

Tongnuanchan, P., Benjakul, S. \& Prodpran, T. 2015. Emulsion film based on fish skin gelatin and palm oil: Physical, structural and thermal properties. Food Hydrocolloids 48 : 248-259.

United States Food and Drug Administration (U.S. FDA). 2009. Code of Federal Regulations Title 21 
Valencia-sullca, C., Vargas, M., Atares, L. \& Chiralt, A. 2017. Thermoplastic cassava starch-chitosan bilayer films containing essential oils. Food Hydrocolloids 19: 53-61.

Wang, L., Liu, F., Jiang, Y., Chai, Z., Li, P., Cheng, Y. \& Jing, H. 2011. Synergistic antimicrobial activities of natural essential oils with chitosan films. Journal of Agricultural and Food Chemistry 59(23): 12411-12419.

Wen, P., Zhu, D.H., Wu, H., Zong, M.H., Jing, Y.R. \& Han, S.Y. 2016. Encapsulation of cinnamon essential oil in electrospun nanofibrous film for active food packaging. Food Control 59: 366-376.

Wendakoon, C. \& Sakaguchi, M. 1995. Inhibition of amino acid decarboxylase activity of Enterobacter aerogenes by active components in spices. Journal of Food Protection 58(3): 280-283.

Wu, J., Sun, X., Guo, X., Ge, S. \& Zhang, Q. 2017. Physicochemical properties, antimicrobial activity and oil release of fish gelatin films incorporated with cinnamon essential oil. Aquaculture and Fisheries 2: 185-192.

Xie, F., Pollet, E., Halley, P.J. \& Avérous, L. 2013. Starch-based nano-biocomposite. Progress in Polymer Science 38: 15901628.

Xing, F., Hua, H., Selvaraj, J.N., Zhao, Y., Zhou, L. \& Liu, X. 2014. Growth inhibition and morphological alterations of Fusarium verticillioides by cinnamon oil and cinnamaldehyde. Food Control 46: 343-350.

Young, R.J., Bannister, D.J., Cervenka, A.J. \& Ahmad, I. 2000. Effect of surface treatment upon the pull-out behaviour of aramid fibres from epoxy resins. Journal of Materials Science 35(8): 1939-1947.

Zainuddin, N., Ahmad, I., Kargarzadeh, H. \& Ramli, S. 2017. Hydrophobic kenaf nanocrystalline cellulose for the binding of curcumin. Carbohydrate Polymers 163: 261-269.

Zhang, Y., Ma, Q., Critzer, F., Davidson, P.M. \& Zhong, Q. 2015. Physical and antibacterial properties of alginate films containing cinnamon bark oil and soybean oil. LWT-Food Science and Technology 64(1): 423-430.

Ummi Habibah Abdullah, Ishak Ahmad* \& Noor Afizah Rosli Jabatan Sains Kimia

Fakulti Sains dan Teknologi

Universiti Kebangsaan Malaysia

43600 UKM Bangi, Selangor Darul Ehsan

Malaysia

Ainon Hamzah

Program Sains Biologi

Fakulti Sains dan Teknologi

Universiti Kebangsaan Malaysia

43600 UKM Bangi, Selangor Darul Ehsan

Malaysia

*Pengarang untuk surat menyurat; email: gading@ukm.edu.my

Diserahkan: 21 Januari 2020

Diterima: 14 April 2020 